\title{
Editorial: Academic Boycotts
}

The University and College Union, the British academics' trade union, has recently called for a 'consistent and complete' boycott of all Israeli academic institutions. The call has been widely attacked, not least, one suspects, because many of those working in Israeli universities are notably critical of current Israeli policy. One could also make the obvious point that a degree of intellectual freedom exists in Israel which one would be hard put to find in many of her neighbours.

The British Academy was quick to condemn the boycott on grounds of principle. In doing so, it quoted a statement from International Human Rights Network of Academies and Scholarly Societies, which stresses the professional duty of scholars to assist 'those colleagues whose human rights have been infringed' and to 'promote and protect the independence of academies and scholarly societies worldwide'.

One can only applaud the sentiments, particularly as applied to this case. But there is a difficulty here in combining the general defence of human rights with the more specific notion of academic freedom; this difficulty may be part of what sometimes fuels calls for academic boycotts.

What if, as has not been unknown, some of those in academies and scholarly societies are using their privileged position to benefit from or promote the denying of rights to others? Should we in the West, for example, have worked with the heavily infiltrated academies in the former Eastern bloc, who did little to help their former colleagues who were stoking boilers? Nearer home, what might we say about the scholarly freedom of an academic who argues against human rights, either generally or in particular cases, and whom some want to silence?

The British Academy calls for 'free academic interchange', laudably enough. But, as Tom Stoppard highlighted in his play Professional Foul, free academic interchange, even among philosophers, might involve some undesirable encounters with academics sheltering beneath the protection of their academies. If, for the best of professional reasons, to promote genuine research and even international co-operation, we undertake such encounters, do we simply have to hope that in the end human rights will win through? It would be interesting to know what Czech dissidents thought of co-operation between Western academics and their academies in the 1970s and 1980s, both at the time and in retrospect. 